\title{
Efektivitas Ekstrak Kulit Buah Limau Kuit (Citrus Amblycarpa) sebagai Larvasida Aedes Aegypti Instar III
}

\section{Effectiveness of Lime Skin Extract (Citrus Amblycarpa) as Natural Larvacide Aedes Aegypti Instar III}

\author{
Nuning Irnawulan Ishak*, Kasman, Chandra \\ Fakultas Kesehatan Masyarakat Universitas Islam Kalimantan MAB Banjarmasin \\ ("nuning.fkm@gmail.com)
}

\begin{abstract}
ABSTRAK
Berbagai dampak negatif penggunaan larvasida kimia mendorong penelitian mengenai larvasida alami salah satunya adalah ekstrak limau kuit. Penelitian ini bertujuan untuk mengetahui efektifitas ekstrak kulit limau kuit sebagai larvasida alami terhadap kematian larva Aedes aegypti. Penelitian ini menggunakan desain true experiment dengan rancangan post test only control group. Objek penelitian adalah ekstrak kulit buah limau kuit. Besar sampel penelitian adalah 450 ekor jentik instar III dengan menggunakan teknik Simple Random Sampling dan diberi perlakuan dengan berbagai konsentrasi ekstrak kulit limau kuit $(2 \mathrm{ml} / 100 \mathrm{ml}, 3 \mathrm{ml} / 100 \mathrm{ml}, 4 \mathrm{ml} / 100 \mathrm{ml}$, dan $5 \mathrm{ml} / 100 \mathrm{ml}$ ) selama $10 \mathrm{jam}$. Kontrol positif menggunakan abate $0,01 \mathrm{gr} / 100 \mathrm{ml}$. Hasil penelitian menunjukkan bahwa semua kelompok perlakuan dapat mematikan 100\% larva. Pada konsentrasi 4,0 ml/100ml dan 5,0 ml/100ml mengalami kematian $100 \%$ setelah 6 jam pengukuran dan kelompok kontrol positif mengalami kematian $100 \%$ setelah 4 jam pengukuran. Analisis data menggunakan uji Kruskal Wallis dan analisis probit. Hasil analisis probit menunjukkan bahwa nilai LT50 konsentrasi 5,0\% adalah 2,58 jam dan nilai LT99 adalah 5,86 jam. Hasil uji Kruskal Wallis menunjukkan tidak terdapat perbedaan secara signifikan $(\mathrm{p}>0,05)$ rerata kematian jentik antar kelompok perlakuan dengan kelompok kontrol. Pemberian ekstrak kulit buah limau kuit dapat menjadi alternatif larvasida alami yang dapat digunakan masyarakat.
\end{abstract}

Kata kunci : Aedes aegypti, limau kuit, larvasida

\section{ABSTRACT}

Various negative effects from the use of chemical larvacides encourage research about natural larvacides, one of which is extract of lime skin extract. This study aimed to determine the effectiveness of lime skin extract as a natural larvacide against the death of Aedes aegypti larvae. This study uses a true experiment design with a post test only control group design. The object of the research was the lime peel extract. The sample size in this study was 450 instar III larvae with Simple Random Sampling technique and treated with various concentrations of lime skin extract $(2 \mathrm{ml} / 100 \mathrm{ml}, 3 \mathrm{ml} / 100 \mathrm{ml}, 4 \mathrm{ml} / 100 \mathrm{ml}$, and $5 \mathrm{ml} / 100 \mathrm{ml})$ for 10 hours. Positive controls use abate $0.01 \mathrm{gr} / 100 \mathrm{ml}$. The results showed that all treatment groups could kill $100 \%$ of larvae. At a concentration of 4.0 $\mathrm{ml} / 100 \mathrm{ml}$ and $5.0 \mathrm{ml} / 100 \mathrm{ml}$ experienced $100 \%$ mortality after 6 hours of measurement and the positive control group experienced $100 \%$ death after 4 hours of measurement. The results of the probit analysis show that the value of LT50 concentration of $5.0 \%$ is 2.58 hours and the value of LT99 is 5.86 hours. The Kruskal Wallis test results showed no significant differences ( $p>0.05$ ) larvae mean mortality between treatment groups and the control group. Giving skin extracts of lime juice can be a natural larvicidal alternative that can be used by the community.

Keywords : Aedes aegypti, citrus amblycarpa, larvacides 


\section{PENDAHULUAN}

Demam Berdarah Dengue adalah jenis penyakit infeksi yang ditularkan oleh nyamuk ${ }^{1}$ dengan empat serotype virus Dengue (DEN 1, 2, 3 $4)^{2}$ di seluruh dunia pada daerah tropis dan subtropis 3456 termasuk di Indonesia. Data WHO dalam kurun waktu 2004-2010, Indonesia menempati urutan pertama negara dengan kasus DBD tertinggi se-Asia sebanyak 129.435 kasus dari 30 negara yang endemis DBD. ${ }^{7}$ Daerah yang menjadi endemik DBD biasanya menjadi sumber penyebaran penyakit ke tempat lain. Setiap Kejadian Luar Biasa (KLB) DBD diawali dengan meningkatnya jumlah kasus di daerah tersebut. ${ }^{8}$ Kalimantan Selatan merupakan salah satu provinsi di Indonesia yang termasuk wilayah endemis DBD. Penyebaran penyakit DBD di wilayah ini terjadi di 13 (tiga belas) kota/kabupaten. Laporan data dari Dinas Kesehatan Kota Banjarmasin menunjukkan bahwa kejadian DBD tahun 2013 tercatat 33 kasus (IR = 89,759 per 100.000 penduduk), tahun 2014 kemudian mengalami penurunan menjadi 11 kasus (IR $=28,86$ per 100.000 penduduk), tahun 2015 mengalami peningkatan lebih 6 kali lipat menjadi 75 kasus ( $I R=172,55$ per 1100.000 penduduk), dan tahun 2016 terjadi 57 kasus (IR $=151,85$ per 100.000 penduduk). ${ }^{9}$

Mengurangi tingkat kepadatan larva nyamuk Aedes aegypti, salah satu cara yang dapat dilakukan untuk mengendalikan vektor DBD adalah menggunakan insektisida sebagai larvasida. Larvasida yang biasa digunakan masyarakat adalah abate (temephos). Akan tetapi penggunaan temephos yang merupakan larvasida kimia terbukti dapat mengakibatkan keracunan pada manusia seperti mual, pusing, dan gangguan saraf lain jika dosis yang diberikan sangat tinggi, polusi lingkungan $^{10}$ bahkan temephos yang digunakan terlalu lama bisa mengakibatkan kerentanan berupa terjadinya resistensi pada vektor penyakit DBD. Banyaknya dampak negatif dari penggunaan larvasida kimia mendorong penelitian mengenai larvasida alami salah satunya adalah ekstrak limau kuit. Penggunaan larvasida alami dari tumbuhan menjadi alternatif insektisida saat ini, juga sebagai pengendalian vektor di masa depan. ${ }^{11}$

Limau kuit merupakan jenis jeruk khas Kalimantan Selatan. Limau kuit populer dengan masyarakat Banjar di Kalimantan Selatan dalam dunia kuliner sebagai penyedap rasa dan bumbu dapur. Limau kuit memiliki kandungan senyawa golongan metabolit sekunder seperti adanya alkaloid, saponin, steroid, triterpenoid, tanin, dan flavonoid. ${ }^{12}$ Senyawa yang terkandung dalam limau kuit seperti alkaloid, tanin, flavonoid, dan saponin diduga dapat berperan sebagai larvasida. Cara kerja alkaloid sebagai racun perut pada serangga dan mampu menghambat pertumbuhan serangga sehingga menyebabkan kegagalan metamorfosis. ${ }^{13}$ Tanin dapat mengganggu aktivitas enzim dan penyerapan makanan sehingga dapat menyebabkan kematian pada larva, sedangkan flavonoid bekerja sebagai racun pernafasan pada serangga. ${ }^{14}$ Tujuan dari penelitan ini untuk mengetahui efektifitas ekstrak kulit buah limau kuit (Citrus amblycarpa) sebagai larvasida alami dalam mematikan larva Aedes aegypti.

\section{BAHAN DAN METODE}

Penelitian ini menggunakan desain true experiment dengan rancangan post test only control group desain. Subjek dibagi menjadi dua kelompok. Kelompok pertama disebut sebagai kelompok perlakuan, yaitu kelompok yang diberi ekstrak kulit buah limau kuit. Kelompok kedua adalah kelompok kontrol positif menggunakan abate $0,01 \mathrm{gr} / 100 \mathrm{ml}$ dan kontrol negatif menggunakan aquades. Penelitian ini dilaksanakan selama 6 bulan (Oktober 2018-Maret 2019) dengan dua tahapan. Tahapan pertama adalah pembuatan ekstrak kulit buah limau kuit di Laboratorium Dasar Universitas Islam Kalimantan MAB Banjarmasin, kemudian pada tahapan kedua adalah pengujian ekstrak kulit buah limau kuit pada larva Aedes aegypti instar III di Laboratorium Entomologi Balai Litbang Kesehatan Kabupaten Tanah Bumbu, Kalimantan Selatan.

Sampel penlitian ini adalah larva Aedes aegypti instar III yang diambil di Balai Litbang P2B2 Tanah Bumbu sebanyak 450 larva Aedes aegypti instar III masing-masing 25 ekor setiap perlakuan dengan pengulangan sebanyak tiga kali untuk setiap kelompok perlakuan dan kelompok kontrol. Pengujian ekstrak kulit limau kuit terhadap larva Aedes aegypti dengan cara larva dimasukkan ke dalam gelas beaker yang telah diisi ekstrak kulit limau kuit dengan konsentrasi 2,0 ml/100 ml, 3,0 $\mathrm{ml} / 100 \mathrm{ml}, 4,0 \mathrm{ml} / 100 \mathrm{ml}$, dan $5,0 \mathrm{ml} / 100 \mathrm{ml}$. seti- 
ap gelas beaker diisi 25 ekor larva. Kemudian ditutup dengan kain kasa dan dilakukan penghitungan dan pencatatan jumlah larva yang mati setiap 1 jam selama 24 jam. Data yang diperoleh dianalisis secara statistik menggunakan analisis univariat untuk melihat tingkat kematian larva dalam setiap kelompok perlakuan. Analisis bivariat untuk melihat perbedaan rerata kematian jentik antar kelompok perlakuan dilakukan uji Kruskal Wallis. Untuk melihat perbedaan tingkat kecepatan kematian larva antar kelompok maka dilakukan Analisis Probit yang dinyatakan dalam Lethal Time (LT) yaitu $\mathrm{LT}_{50}$ dan $\mathrm{LT}_{99}$.

\section{HASIL}

Penelitian ini menggunakan 2 kelompok perlakuan yaitu meliputi kelompok ekstrak kulit buah limau kuit dan kelompok kontrol. Buah limau kuit yang digunakan adalah buah dengan kondisi kulit yang masih berwarna hijau tua. Pertimbangan ini didasarkan karena limau kuit yang berwarna hijau tua merupakan kulit buah yang masih segar tidak terdapat kerusakan. Variasi konsentrasi yang digunakan untuk ekstrak kulit buah limau kuit adalah $2,0 \%, 3,0 \%, 4,0 \%$ dan $5,0 \%$ dengan 3 kali pengulangan.

Analisis univariat dilakukan untuk melihat tingkat kematian Aedes aegypti Instar III pada semua kelompok. Tabel 1 menunjukkan perbedaan tingkat kematian masing-masing kelompok uji. Kelompok perlakuan menggunakan ekstrak kulit limau kuit menunjukkan kematian 100\% le- bih cepat pada konsentrasi $4,0 \mathrm{ml} / 100 \mathrm{ml}$ dan 5,0 $\mathrm{ml} / 100 \mathrm{ml}$ setelah 6 jam pengukuran. Pada kelompok kontrol positif dengan abate $0,01 \mathrm{gr} / 100 \mathrm{ml}$ mengalami kematian $100 \%$ setelah 4 jam pengukuran. Sementara kelompok kontrol negatif dengan aquades tidak mengalami kematian. Hasil penelitian ini menunjukkan kematian pada semua kelompok perlakuan setelah 10 jam pengamatan.

Gambar 1 menunjukkan kondisi kematian larva Aedes aegypti Instar III dari semua kelompok perlakuan ekstrak kulit buah limau kuit di semua konsentrasi yaitu 2,0 $\mathrm{ml}, 3,0 \mathrm{ml}, 4,0 \mathrm{ml}$ dan $5,0 \mathrm{ml}$ dengan jumlah kematian larva sebanyak 25 ekor $(100 \%)$ yang terlihat di semua kontainer kelompok perlakuan. Larva yang telah mati bisa dipastikan jika larva tidak bergerak saat dirangsang menggunakan lidi atau spatula dan biasanya akan tenggelam ke dasar gelas beaker, terdapat juga beberapa larva yang mati dalam kondisi mengapung, yang terlihat dari kelompok perlakuan setelah pemberian ekstrak kulit limau kuit.

Gambar 2 menunjukkan adanya perbandingan kondisi larva Aedes aegypti instar III pada setiap kelompok. Aquades tidak memiliki efek larvasida sehingga tidak terdapat larva yang mati. Sedangkan untuk abate dan kelompok perlakuan, memberikan efek larvasida sehingga larva uji mengalami kematian yang ditandai adanya kerusakan secara morfologis terutama kerusakan pada siphon. Larva uji yang mati juga terlihat mengalami perubahan warna lebih transparan pada tubuh larva.

Tabel 1. Perbandingan Tingkat Kematian Larva Aedes aegypti Instar III Pada Semua Kelompok Perlakuan dan Kelompok Kontrol

\begin{tabular}{|c|c|c|c|c|c|c|}
\hline \multirow{3}{*}{ Jam } & \multicolumn{6}{|c|}{ Kematian Larva (\%) } \\
\hline & \multicolumn{4}{|c|}{ Ekstrak Kulit } & \multirow{2}{*}{$\mathbf{K}+$} & \multirow{2}{*}{$\mathbf{K}-$} \\
\hline & $2,0 \mathrm{ml}$ & $3,0 \mathrm{ml}$ & $4,0 \mathrm{ml}$ & $5,0 \mathrm{ml}$ & & \\
\hline 1 & 0,00 & 0,00 & 0,00 & 0,00 & 2,67 & 0,00 \\
\hline 2 & 18,67 & 17,33 & 26,67 & 30,67 & 26,67 & 0,00 \\
\hline 3 & 30,67 & 41,33 & 42,67 & 54,67 & 50,67 & 0,00 \\
\hline 4 & 89,33 & 85,33 & 93,33 & 93,33 & 100,00 & 0,00 \\
\hline 5 & 96,00 & 93,33 & 96,00 & 96,00 & 100,00 & 0,00 \\
\hline 6 & 97,33 & 98,67 & 100,00 & 100,00 & 100,00 & 0,00 \\
\hline 7 & 100,00 & 100,00 & 100,00 & 100,00 & 100,00 & 0,00 \\
\hline 8 & 100,00 & 100,00 & 100,00 & 100,00 & 100,00 & 0,00 \\
\hline 9 & 100,00 & 100,00 & 100,00 & 100,00 & 100,00 & 0,00 \\
\hline 10 & 100,00 & 100,00 & 100,00 & 100,00 & 100,00 & 0,00 \\
\hline
\end{tabular}

Sumber : Data Primer, 2019 
Tabel 2. Perbedaan Rerata Kematian Jentik Kelompok Perlakuan Ekstrak Kulit Buah Dengan Kelompok Kontrol

\begin{tabular}{cccc}
\hline Waktu Pengukuran & Chi Square & $\boldsymbol{d f}$ & Sig. \\
\hline 1 jam & 5,000 & 4 & 0,416 \\
2 jam & 7,647 & 4 & 0,105 \\
3 jam & 7,356 & 4 & 0,118 \\
4 jam & 8,482 & 4 & 0,075 \\
5 jam & 6,816 & 4 & 0,146 \\
6 jam & 6,222 & 4 & 0,183 \\
7 jam & 0,000 & 4 & 1,000 \\
8 jam & 0,000 & 4 & 1,000 \\
\hline
\end{tabular}

Sumber : Data Primer, 2019

Tabel 3. Nilai LT dan $_{50}$ LT $_{99}$ Kematian Larva Aedes aegypti Instar III Kelompok Perlakuan Ekstrak Kulit Buah Limau Kuit

\begin{tabular}{|c|c|c|c|c|c|c|}
\hline \multirow{2}{*}{ Konsentrasi } & \multirow{2}{*}{$\underset{\text { (jam) }}{\text { Nilai LT }_{50}}$} & \multicolumn{2}{|c|}{ Batas Kepercayaan 95\% } & \multirow{2}{*}{$\begin{array}{l}\text { Nilai LT }_{99} \\
\quad \text { (jam) }\end{array}$} & \multicolumn{2}{|c|}{ Batas Kepercayaan 95\% } \\
\hline & & Minimum & Maksimum & & Minimum & Maksimum \\
\hline $2,0 \%$ & 2,99 & 2,64 & 3,31 & 6,39 & 5,39 & 8,47 \\
\hline $3,0 \%$ & 2,95 & 2,78 & 3,12 & 6,45 & 5,83 & 7,34 \\
\hline $4,0 \%$ & 2,73 & 2,41 & 3,02 & 5,98 & 5,04 & 7,95 \\
\hline $5,0 \%$ & 2,58 & 2,40 & 2,74 & 5,86 & 5,26 & 6,77 \\
\hline Kontrol + & 2,66 & 2,11 & 3,03 & 4,97 & 4,12 & 7,88 \\
\hline Kontrol - & - & - & - & - & - & - \\
\hline
\end{tabular}

Sumber : Data Primer, 2019

Uji Kruskal Wallis dilakukan untuk melihat perbedaan rerata kematian larva antar kelompok (Tabel 2). Terdapat perbedaan rerata kematian larva setiap jam pada kelompok perlakuan Ekstrak Kulit dengan kelompok kontrol menggunakan abate. Hasil uji Kruskal Wallis memperlihatkan tidak ada perbedaan secara signifikan $(>0,05)$ rerata kematian jentik antar kelompok perlakuan limau kuit dengan kelompok kontrol menggunakan abate.

Tabel 3 menunjukkan estimasi waktu yang dibutuhkan dalam mematikan larva 50\% dan 99\%. Untuk konsentrasi ekstrak kulit limau kuit 2,0\% dibutuhkan waktu 2,99 jam dalam mematikan $50 \%$ larva dan dibutuhkan waktu 6,39 jam dalam mematikan 99\% larva. Untuk konsentrasi ekstrak kulit limau kuit 5,0\% dibutuhkan waktu 2,58 jam dalam mematikan 50\% larva dan dibutuhkan waktu 5,86 jam dalam mematikan 99\% larva.

\section{PEMBAHASAN}

Hasil penelitian ini membuktikan bahwa penggunaan ekstrak kulit buah limau kuit menyebabkan 100\% kemtian larva Aedes aegypti instar III pada semua kelompok perlakuan dengan kon- sentrasi $2,0 \%, 3,0 \%, 4,0 \%$, dan 5,0\%. Perbedaan kematian hanya dapat dilihat dari lamanya waktu paparan konsentrasi, semakin besar konsentrasi ekstrak yang diberikan semakin cepat pula tingkat kematian larva uji.

Kondisi air setelah pemberian ekstrak kulit buah dari segi fisiknya mengalami perubahan. Ekstrak kulit yang telah dibuat pada dasarnya berwarna hijau kekuningan, sehingga ketika dicampurkan dengan aquades warna air menjadi keruh dan memiliki bau limau kuit yang khas. Parameter kimia air bersih yaitu derajat keasaman $(\mathrm{pH})$, air memiliki pH 7 yang merupakan tempat perkembangan optimal bagi larva nyamuk Aedes aegy$p t i .^{15}$ Permenkes No.415/Menkes/Per/IX/1990, $\mathrm{pH}$ media air yang diperbolehkan yaitu 6,5-8,5. ${ }^{8}$ Kelompok perlakuan, $\mathrm{pH}$ air setelah diberikan ekstrak kulit limau kuit berubah menjadi asam yaitu berkisar antara 4,7-4,8. Kondisi air yang berubah menjadi asam dari pemberian ekstrak memiliki kelebihan dalam penggunaannya, yaitu tidak mudah menimbulkan resisten pada larva dan tidak mencemari lingkungan karena mudah terurai. ${ }^{16}$

Berdasarkan pengamatan yang telah dilakukan selama 24 jam, temephos tetap memiliki efek 


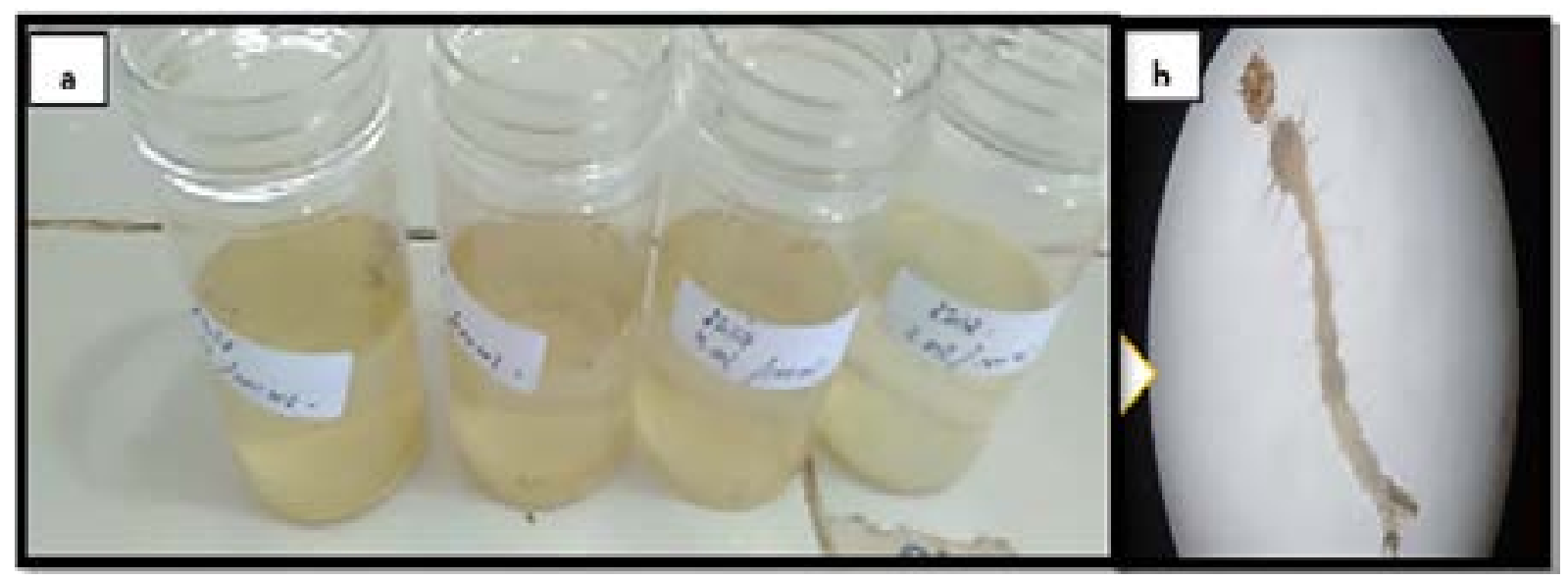

Gambar 1. a) Kondisi Kematian Larva Aedes aegypti Instar III pada Kelompok Perlakuan Pemberian Ekstrak Kulit Buah Limau Kuit, b) Salah Satu Larva Aedes aegypti Instar III yang telah mati

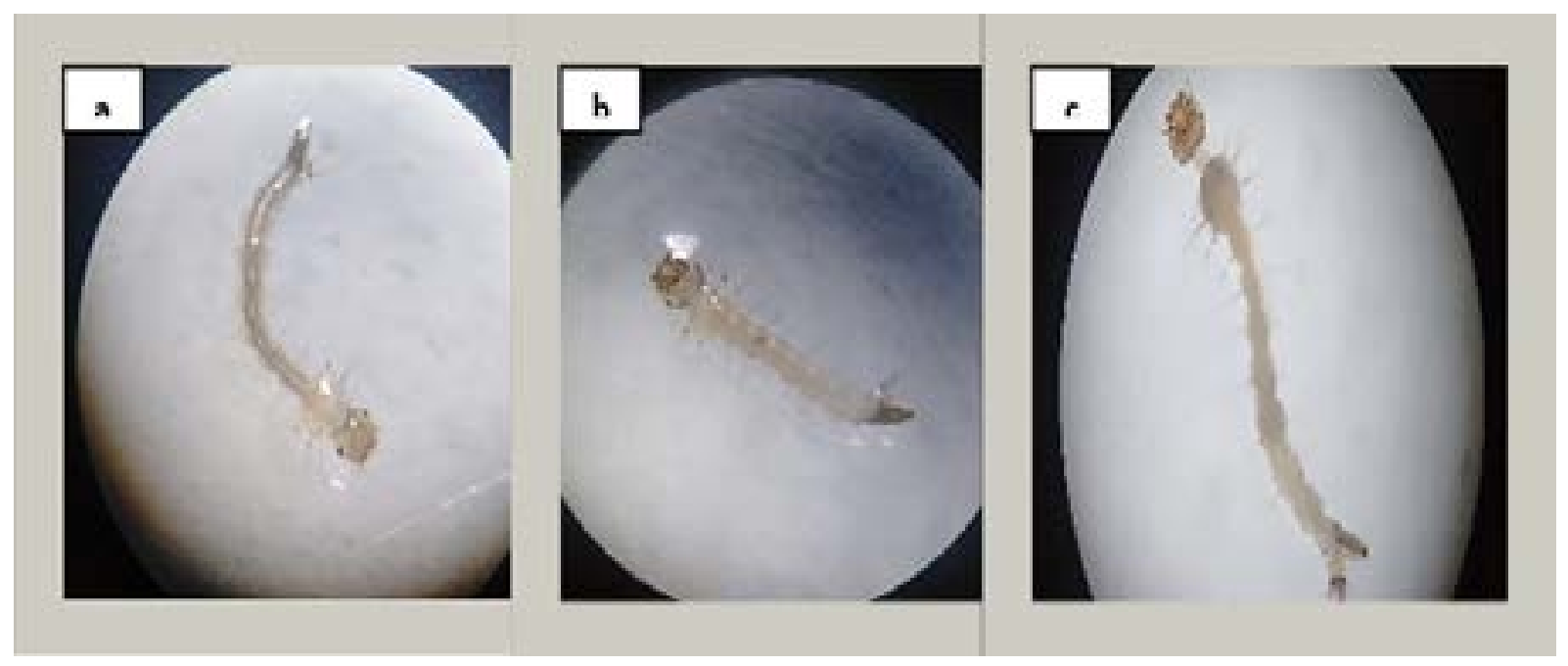

Gambar 2. Perbandingan Kondisi Larva Aedes aegypti Instar III pada Kelompok Kontrol dan Kelompok Perlakuan

a) Larva yang tetap Hidup dari Kelompok Kontrol (-) Aquades, b) Larva tang Mati tari Kelompok Kontrol (+) Abate, c) Larva yang Mati dari Kelompok Perlakuan Ekstrak Kulit Buah Limau Kuit

larvasida paling baik dengan rata-rata $\%$ kematian larva uji sebesar $100 \%$. Sedangkan aquades tidak memiliki efek larvasida sehingga tidak menyebabkan larva uji mati. Ini disebabkan karena aquades atau air merupakan habitat larva nyamuk Aaedes aegypti dan tidak mengandung zat toksik. ${ }^{15}$

Kematian larva Aaedes aegypti terdapat pada semua kelompok perlakuan yang diberikan ekstrak kulit buah limau kuit. Pada 1 jam pertama mulai terjadi tanda-tanda kematian larva uji ketika ekstrak diteteskan ke dalam kontainer yang berisi larva uji. Larva terlihat mengalami kejang-kejang dan membengkokkan badan. Kematian mulai terjadi di semua konsentrasi pada pengamatan 2 jam berikutnya. Kelompok perlakuan menggunakan ekstrak kulit limau kuit menunjukkan kematian $100 \%$ setelah 6 jam pengukuran pada konsentrasi $4,0 \mathrm{ml} / 100 \mathrm{ml}$ dan $5,0 \mathrm{ml} / 100 \mathrm{ml}$.

Kematian larva Aedes aegypti berbanding lurus dengan lama waktu paparan dan besarnya konsentrasi ekstrak limau kuit yang diberikan. Hal ini membuktikan bahwa semakin tinggi konsentrasi ekstrak kulit buah limau kuit yang diberikan maka semakin tinggi dan cepat juga kematian 
larva uji akibat efek larvasida pada ekstrak limau kuit. Hasil penelitian ini sejalan dengan penelitian Husnawati, semakin meningkat konsentrasi ekstrak daun kirinyuh maka kandungan zat toksik pada media hidup larva juga semakin meningkat sehingga jumlah zat toksik yang masuk ke dalam tubuh larva juga semakin banyak sehingga larva lebih mudah mengalami kematian. ${ }^{17}$ Hasil penelitian Arimaswati, dkk juga menyatakan bahwa peningkatan konsentrasi ekstrak biji buah papaya (C.papaya L.) berbanding lurus dengan meningkatnya efek larvasida karena konsentrasi larutan semakin pekat. ${ }^{18}$

Kematian larva Aedes aegypti instar III dalam penelitian ini kemungkinan disebabkan adanya senyawa metabolik sekunder pada ekstrak kulit buah limau kuit. Penelitian Irwan, dkk menyatakan bahwa hasil uji fitokimia sampel limau kuit untuk ekstrak kulit, semuanya memberikan hasil uji positif adanya kandungan alkaloid, tannin, saponin, dan flavonoid. Sedangkan untuk ekstrak perasan buah, memberikan hasil uji positif adanya kandungan saponin, tanin alkaloid, dan negatif pada flavonoid. ${ }^{12}$ Senyawa aktif biji mahoni memiliki kandungan senyawa allelokimia, seperti flavonoid dan saponin. ${ }^{19}$ Kandungan ini yang diperkirakan bisa mematikan larva uji Aedes aegypti. Tanaman di Indonesia memiliki potensi besar untuk dimanfaatkan sebagai larvasida nabati. ${ }^{20}$ Senyawa kimia pertahanan tumbuhan seperti saponin, terpenoid, alkaloid dan flavonoid yang dihasilkan pada jaringan tumbuhan dan memiliki sifat toksik bagi serangga dengan mengurangi kemampuan mencerna makanan. ${ }^{13}$

Alkoloid merupakan senyawa pertahanan tumbuhan bersifat toksik memiliki sifat mengganggu makan serangga. Senyawa alkoloid bisa menghambat pertumbuhan serangga. Alkaloid dapat mendegradasi membran sel untuk masuk ke dalam dan merusak sel. Selain itu juga dapat mengganggu sistem kerja syaraf larva dengan mengganggu kinerja enzim asetil kolinesterase. Alkaloid juga membuat warna tubuh larva berubah menjadi lebih transparan dan apabila mendapat rangsangan sentuhan gerakan tubuh larva menjadi lambat serta badan larva terlihat selalu membengkok. ${ }^{19}$ Pada gambar 1 terlihat kematian larva uji yang bisa dilihat dengan berubahnya warna tubuh larva terlihat lebih transparan.
Kandungan saponin pada ekstrak kulit buah limau kuit bekerja sebagai racun perut pada larva. Saponin dapat menghambat dan mematikan larva dengan cara merusak membran sel serta mengganggu proses metabolism larva. Senyawa saponin sebagai racun perut (stomach poisoning) mengganggu kemampuan makan dengan menyerang sistem pencernaan. Senyawa tersebut masuk melalui saluran pencernaan sehingga mengganggu alat pencernaan. ${ }^{21}$ Mekanisme kerja saponin dengan cara mendenaturasi protein dan enzim di dalam sel. Saponin bisa berdifusi melalui membran luar serta dinding sel yang rentan kemudian mengikat membran sitoplasma sehingga memberi gangguan dan mengurangi kestabilan membran sel. Kondisi ini membuat sitoplasma bocor keluar dari sel sehingga mengalami kematian. ${ }^{18}$

Selain senyawa saponin, tanin juga memiliki fungsi sebagai racun perut yang dapat mengganggu kerja enzim dalam mengikat protein pada sistem pencernaan serangga sehingga mengganggu proses pencernaan larva Aedes aegypti. Tanin memiliki fungsi larvasida sebagai sebagai racun perut (stomach poisoning). Ini dikarenakan tanin dapat mengganggu kerja enzim dengan cara membentuk ikatan kompleks dengan protein pada enzim dan substrat yang dapat mengakibatkan gangguan pada pencernaan larva dan merusak dinding sel. ${ }^{18}$ Proses penyerapan senyawa kimia tersebut sebagian besar terjadi pada saluran pencernaan bagian tengah (midgut) yang merupakan organ pencernaan serangga yang utama. Saluran ini merupakan organ penyerap nutrisi dan sekresi enzim-enzim pencernaan. Hal ini dikarenakan saluran bagian tengah (midgut) memiliki struktur yang tidak memiliki kutikula, sementara saluran bagian depan (foregut) dan saluran akhir (hindgut) memiliki lapisan kutikula. Apabila saluran pencernaan bagian tengah rusak, aktivitas enzim akan terganggu sehingga proses pencernaan tidak maksimal hingga mengakibatkan metabolisme tubuh serangga menjadi tidak terkendali. ${ }^{22}$

Flavonoid merupakan jenis fenol alam yang terbesar mengandung banyak pigmen yang dimiliki seluruh dunia tumbuhan. Flavonoid masuk ke dalam tubuh larva melalui sistem pernapasan dan akan menimbulkan kelayuan pada syaraf serta kerusakan pada sistem pernapasan sehingga larva tidak bisa bernapas dan akhirnya mati. ${ }^{19}$ Flavonoid 
bekerja sebagai inhibitor pernapasan yang merupakan zat untuk menghambat atau menurunkan laju reaksi kimia. ${ }^{22}$

Senyawa aktif yang terkandung dalam ekstrak kulit buah limau kuit dapat dikatakan perpaduan senyawa aktif berupa alkaloid, saponin, tanin, dan flavonoid yang memiliki efek toksik bagi larva. Senyawa bioaktif ini merupakan penyebab kematian larva karena tidak mampu mendetoksifikasi senyawa toksik yang masuk ke dalam tubuh larva.

Penggunaan ekstrak kulit buah limau kuit memiliki potensi yang dapat dimanfaatkan sebagai biolarvasida dengan kandungan senyawa metabolik sekunder berupa alkaloid, saponin, flavonoid dan tanin, yang dapat memberikan gangguan dan mematikan larva Aedes aegypti instar III. Mekanisme kerja larvasida dalam mematikan larva melalui tiga cara yaitu sebagai racun kontak (contac poisoning) dapat melalui dinding tubuh larva melalui kontak dengan kulit, menembus kutikula, trakea atau kelenjar sensorik dan organ lain yang berhubungan dengan kutikula. Dinding tubuh serangga merupakan bagian tubuh serangga yang dapat menyerap zat toksik dalam jumlah besar. Sebagai racun perut (stomach poisioning) melalui mulut dan sebagai racun pernafasan (fumigan). ${ }^{18} 22$

Hasil penelitian ini membuktikan bahwa penggunaan ekstrak kulit buah limau kuit mengakibatkan 100\% kematian larva Aedes aegypti instar III pada semua kelompok perlakuan. Perbedaan kematian hanya dapat dilihat dari lamanya waktu paparan konsentrasi, semakin besar konsentrasi ekstrak yang diberikan semakin cepat pula tingkat kematian larva uji.

Hasil uji probit memperlihatkan bahwa nilai $\mathrm{LT}_{50}$ yakni waktu yang diperlukan untuk mematikan 50\% larva Aedes aegypti instar III menggunakan ekstrak kulit dengan konsentrasi 5,0\% adalah 2,58 jam dan nilai $\mathrm{LT}_{99}$ yaitu waktu yang dibutuhkan untuk mematikan 99\% larva Aedes aegypti instar III menggunakan ekstrak kulit dengan konsentrasi 5,0\% adalah 5,86 jam. Sedangkan Hasil uji probit memperlihatkan bahwa nilai $\mathrm{LT}_{50}$ yakni waktu yang dibutuhkan untuk mematikan 50\% larva Aedes aegypti instar III menggunakan ekstrak kulit buah dengan konsentrasi 5,0\% adalah 2,26 jam dan nilai $\mathrm{LT}_{99}$ yaitu waktu yang diperlukan untuk mematikan 99\% larva Aedes ae- gypti instar III menggunakan ekstrak kulit buah dengan konsentrasi 5,0\% adalah 3,99 jam. Sehingga, hasil penelitian ini membuktikan bahwa semakin besar konsentrasi yang diberikan dan semakin lama waktu perlakuan bisa menambah jumlah larva Aedes aegypti instar III yang mati.

Temephos (abate) bersifat mematikan larva Aedes aegypti dan merupakan insektisida golongan organofosfat yang memiliki kemampuan sebagai racun yang mempengaruhi sistem neurotransmitter. ${ }^{23}$ Apabila diamati dari segi kerusakan tubuh yang ditimbulkan, kerusakan tubuh larva lebih parah oleh pemberian ekstrak kulit buah limau kuit dibandingkan dengan abate (Gambar 2). Hal ini mungkin disebabkan karena cara kerja abate yang berbeda dengan ekstrak kulit buah limau kuit dimana pemberian ekstrak merusak kutikula dan saluran pencernaan larva sedangkan abate bekerja dengan mempengaruhi sistem syaraf. ${ }^{17}$ Hasil penelitian yang telah dilakukan menunjukkan kelompok kontrol positif dalam hal ini abate memang lebih cepat 1 jam dalam menyebabkan kematian larva Aedes aegypti instar III dibandingkan ekstrak kulit buah limau kuit. Namun, penggunaan abate sebagai larvasida tetap perlu diperhatikan. Hal ini disebabkan karena abate merupakan larvasida sintetis yang berpotensi menyebabkan pencemaran ${ }^{24}$ menyebabkan terjadinya kasus resistensi pada larva yang diduga akibat penggunaan dosis yang tidak sesuai dengan anjuran pemerintah. ${ }^{25}$ Apabila abate digunakan secara berlebihan maka akan mengakibatkan overstimulasi saraf sehingga masyarakat yang mengkonsumsinya dapat mengalami pusing, mual, dan kebingungan. ${ }^{8}$

Hasil uji Kruskal Wallis untuk melihat perbedaan rerata kematian larva setiap jam pada kelompok perlakuan ekstrak kulit buah dengan kelompok kontrol menggunakan temephos (abate) menunjukkan tidak terdapat perbedaan secara signifikan $(>0,05)$. Kedua jenis larvasida tersebut tidak memiliki perbedaan daya bunuh yang signifikan. Lama waktu mematikan larva Aedes aegypti instar III tidak berbeda secara signifikan berdasarkan uji statistik. Sehingga dapat dikatakan pemberian ekstrak kulit buah limau kuit dapat menjadi alternatif larvasida alami yang dapat digunakan masyarakat dan lebih aman berbahan dasar tumbuhan sehingga tidak berbahaya bagi kesehatan manusia dan ramah lingkungan. 
Banyaknya dampak negatif dari penggunaan larvasida kimia mendorong penelitian mengenai larvasida alami dari tumbuhan sebagai pengendalian vektor di masa depan. ${ }^{11}$ Hasil penelitian ini masih perlu dilakukan uji lanjutan dengan menggunakan ekstrak kulit limau kuit sebagai larvasida alami pada daerah endemis DBD. Hal ini perlu dilakukan untuk mengetahui efek langsung di masyarakat. Karena larva yang didapatkan dari laboratorium akan berbeda dengan larva yang ada di lapangan.

\section{KESIMPULAN}

Kelompok perlakuan menggunakan ekstrak kulit buah limau kuit menunjukkan 100\% kematian setelah 6 jam pengamatan pada konsentrasi 4,0 $\mathrm{ml} / 100 \mathrm{ml}$ dan $5,0 \mathrm{ml} / 100 \mathrm{ml}$. Pada kelompok kontrol positif dengan abate $0,01 \mathrm{gr} / 100 \mathrm{ml}$ mengalami kematian $100 \%$ setelah 4 jam pengukuran. Sementara kelompok kontrol negatif dengan aquades tidak mengalami kematian. Hasil penelitian menunjukkan bahwa tidak terdapat perbedaan secara signifikan $(>0,05)$ rerata kematian jentik antar kelompok perlakuan limau kuit dengan kelompok kontrol menggunakan abate. Semakin besar konsentrasi yang diberikan dan semakin lama waktu perlakuan dapat menambah jumlah kematian larva Aedes aegypti instar III. Penggunaan ekstrak kulit buah limau kuit dapat menjadi alternatif larvasida alami larva Aedes aegypti. Perlu dilakukan penelitian lebih lanjut untuk mengetahui konsentrasi minimal yang dibutuhkan untuk mematikan larva Aedes aegypti.

\section{DAFTAR PUSTAKA}

1. Muh. Jusman Rau, Adhar Arifuddin, Sylvia Afrianti P. The Analysis of Environmental Risk and the Use of Repellent on Dengue Hemorrhagic Fever in Kamonji Public Health Center. Journal Current Medical Research and Opinion. 2019;2(5):144-147.

2. Harapan H, Michie A, Mudatsir M, Sasmono RT, Imrie A. Epidemiology of Dengue Hemorrhagic Fever in Indonesia: Analysis of Five Decades Data From the National Disease Surveillance. BMC Research Notes. 2019;12(350):1-6.

3. Angeline G, Kularatnam M, Jasinge E, Gunasena S, Samaranayake D. Evaluation of
Biochemical and Haematological Changes in Dengue Fever and Dengue Hemorrhagic Fever in Sri Lankan Children: a Prospective Follow up Study. BMC Pediatrics. 2019;19(87):1-9.

4. Lauer SA, Sakrejda K, Ray EL, Keegan LT, Bi Q, Suangtho P. Prospective Forecasts of Annual Dengue Hemorrhagic Fever Incidence in Thailand, 2010-2014. Proceedings of the National Academy of Sciences. 2018;115(10):2175-2182.

5. Yang, Fen Lin, Hui Yang, Lin Zhang, Sen-Hai Fang, Xiao-Fen Zhan L-YY. The Analysis of Clinical and Laboratory Data: a Large Outbreak of Dengue Fever in Chaozhou, Guangdong Province, China. Archives of Virology. 2019;164(8):2131-2135.

6. Ningrum DS, Pramatama S, Wijayanti M. Mosquito Larvacidal Activity of Zingiber Montanum Rhizome Extract Against Aedes Aegypti Larvae. BALABA. 2019;15(1):3340.

7. WHO. Global Strategy for Dengue Prevention and Control. WHO; 2012.

8. Manyullei S, Ishak H, Ekasari R. Perbandingan Efektivitas Air Perasan Kulit Jeruk Manis dan Temephos terhadap Kematian Larva Aedes Aegypti Comparative Efficiency of the Juice of Sweet Orange Peel and Temephos on Aedes Aegypti Larvae Efficacy. MKMI. 2015;11(1):23-31.

9. Nuning Irnawulan Ishak K. The Effect of Climate Factors for Dengue Hemorrhagic Fever in Banjarmasin City, South Kalimantan Province, Indonesia, 2012-2016. Public Health of Indonesia. 2018;4(3):121-128.

10. Ratih Dewi Dwiyanti, Rion Dediq AT. Daya Bunuh Ekstrak Air Daun Salam (Syzygium polyanthum) terhadap Larva Aedes sp. Medical Laboratory Technology Journal. 2017;3(1):93-97.

11. Muangmoon R, Junkum A, Chaithong U. Natural Larvicides of Botanical Origin Against Dengue Vector Aedes Aegypti (Diptera: Culicidae). Southeast ASIAN J Trop Med Public Health. 2018;49(2):227-239.

12. Azidi Irwan, Kamilia Mustikasari DA. Pemeriksaan Pendahuluan Kimia Daun, Kulit dan Buah Limau Kuit: Jeruk Lokal Kalimantan Selatan. Sains dan Terapan Kimia. 
2017;11(2):71-79.

13. Tinneke Lumowa SV PNT. Larvicidal Activity of Syzygium Polyanthum W. Leaf Extract Against Aedes Aegypti L Larvae. Progress in Health Sciences. 2015;5(1):102-106.

14. Lubis R, Ilyas S, Panggabean M. The Effectivity Test of Aloe Vera Leaf Extract to Larvae Aedes SP. Asian Journal of Pharmaceutical Clinical Research. 2018;11(7):262-266.

15. Amalia R. Daya Bunuh Air Perasan Daun Mengkudu (Morinda citrifolia) terhadap Kematian Larva Aedes aegypti. [Skripsi]. Semarang: Universitas egeri Semarang; 2016.

16. Wati WE, Astuti D, Darnoto S. Beberapa Faktor yang Berhubungan dengan Kejadian Demam Berdarah Dengue (DBD) di Kelurahan Ploso Kecamatan Pacitan Tahun 2009. VEKTORA. 2011;3(1):22-34.

17. Husnawati, Prapti SedijaniNL. Efektivitas Ekstrak Etanol Daun Kirinyuh (Eupatorium odoratum L) terhadap Mortalitas Larva Nyamuk Aedes aegypti sebagai Pengayaan Praktikum Fisiologi Hewan. Mataram; 2018.

18. Arimaswati, Sawaluddin OM, Sudrajat HW. Efek Larvasida Ekstrak Biji Buah Pepaya ( Carica papaya L .) terhadap Larva Instar III A edes aegypti L . MEDULA. 2017;4(April):332-343

19. Koneri R, Pontororing HH. Uji Ekstrak Biji Mahoni (Swietenia Macrophylla) terhadap Larva Aedes aegypti Vektor Penyakit Deman Berdarah. MKMI. 2016;12(4):216-223.
20. Yoke Astriani MW. Potensi Tanaman di Indonesia sebagai Larvasida Alami untuk Aedes Aegypti. SPIRAKEL. 2018;8(2017):37-46.

21. Yoma Seivia F. Tarukbua, Edwin De Queljoe WB. Skrining Fitokimia dan Uji Toksisitas Ekstrak Etanol Daun Brotowali (Tinospora Crispa (L.) Hook F . \& T) dengan Metode Brine Shrimp Lethality Test (BSLT). PHARMACON Jurnal Ilmu Farmasi. 2018;7(3):330337.

22. Ifa Ahdiyah KIP. Pengaruh Ekstrak Daun Mangkokan (Nothopanax scutellarium) Sebagai Larvasida Nyamuk Culex sp. Jurnal Sains dan Seni ITS. 2015;4(2):2337-3520.

23. Nur Handayani, Ludfi Santoso, Martini SP. Status Resistensi Larva Aedes Aegypti terhadap Temephos di Wilayah Perimeter dan Buffer Pelabuhan Tanjung Emas Kota Semarang. Jurnal Kesehatan Masyarakat. 2016;4(3):159166.

24. Indri Ramayanti RF. Uji Efektivitas Larvasida Ekstrak Daun Pepaya (Carica papaya Linn) terhadap Larva Aedes aegypti. Syifa'MEDIKA: Jurnal Kedokteran dan Kesehatan. 2016;6(2):79-88.

25. Istiana, Heriyani F, Isnaini. Status Kerentanan Larva Aedes Aegypti terhadap Temefos di Banjarmasin Barat. Jurnal BUSKI: Epidemiologi dan Penyakit Bersumber Binatang (Epidemiology Zoonosis Journal). 2012;4(2):5358. 